\title{
Simultaneous photoinduced electron transfer and photoinduced CuAAC processes for antibacterial thermosets
}

\author{
Elif $\mathrm{Oz}^{\mathrm{a}}$, Tamer Uyar ${ }^{\mathrm{b}}$, Huseyin Esen ${ }^{\mathrm{a}, *}$, Mehmet Atilla Tasdelen ${ }^{\mathrm{a}, *}$ \\ a Department of Polymer Engineering, Faculty of Engineering, Yalova University, 77100, Yalova, Turkey \\ ${ }^{\mathrm{b}}$ UNAM-Institute of Materials Science and Nanotechnology, Bilkent University, TR-06800 Ankara, Turkey
}

\section{A R T I C L E I N F O}

\section{Article history:}

Received 22 September 2016

Received in revised form 7 December 2016

Accepted 14 January 2017

Available online 5 February 2017

\section{Keywords:}

Antibacterial properties

Copper-catalyzed azide-alkyne

cycloaddition click chemistry

Nanocomposites

Photopolymerization

Silver nanoparticles

Thermosets

\begin{abstract}
A B S T R A C T
A combination of simultaneous photoinduced electron transfer and photoinduced CuAAC processes enables the in-situ preparation of antibacterial thermosets containing silver nanoparticles (AgNPs) in one-pot. Upon photolysis of photoinitator, the generated radicals not only reduce $\mathrm{Cu}(\mathrm{II})$ into $\mathrm{Cu}(\mathrm{I})$ activator to catalyst the CuAAC click reaction, but also simultaneously generate $\mathrm{AgNPs}$ from $\mathrm{AgNO}_{3}$ through electron transfer reaction. Due to their reduction potentials difference, the polymer matrix is formed before the formation of AgNPs, assisting to eliminate the agglomeration of them. The thermoset structures are confirmed by FT-IR and solubility tests, whereas the presence of AgNPs is proven by transmission electron microscopy with energy dispersive X-ray system analyzer. The samples containing 5 and 10\% AgNPs exhibited strong inhibition zones, where all kinds of bacteria (gram-positive (Staphylococcus Aureus) and gram-negative (Escherichia Coli)) were killed in the surrounding of the film samples.
\end{abstract}

(c) 2017 Elsevier B.V. All rights reserved.

\section{Introduction}

Antibacterial materials have been widely used in daily life due to its important role in human health and safety [1]. Based on their nature, they can be divided into two categories as organic and inorganic antibacterial materials [2]. While the organic antibacterial materials are considered less stable, particularly at high temperatures and/or pressures, the inorganic metals and metal oxides have been widely used due to their fine chemical durability and high antibacterial activity [3]. Among them, the silver (Ag) and its salts have efficiently been employed as antibacterial agent against bacteria, fungi, and viruses [4]. Since a particle size is one of the most significant factors affecting antibacterial efficacy, the Ag nanoparticles (AgNPs) have displayed a superior antibacterial activity compared to the microparticles [3]. The smaller nanoparticles have a greater surface area to volume ratio where they can potentially release more silver ions and are able to directly interact with the microorganisms [5]. There are several chemical methods to produce AgNPs such as chemical reduction [6,7], photochemical

\footnotetext{
* Corresponding authors.

E-mail addresses: huseyin.esen@yalova.edu.tr (H. Esen), tasdelen@yalova.edu.tr (M.A. Tasdelen).
}

reduction [8-17], sol-gel synthesis [18,19], hydrothermal [20,21], electrodeposition [22,23] and polyol [24,25] methods. Recently, a new strategy based on a simultaneous photoreduction of $\mathrm{Ag}(\mathrm{I})$ and photopolymerization enables to fabricate polymer nanocomposites containing AgNPs in one-pot [9-13]. The photogenerated radicals can be utilized for the reduction of $\mathrm{Ag}(\mathrm{I})^{+}$cation into $\operatorname{Ag}(0)$ nanoparticles as well as the initiation of multifunctional monomers [26-29]. The photoreduction mechanism is based on the electron-transfer from reducing intermediates (free radicals, solvated electrons, and anions, which generated by a photoactive compound under UV or visible light) to the $\mathrm{Ag}^{+}$producing a very rapid and efficient formation of AgNPs [30].

The photoinduced copper(I)-catalyzed azide-alkyne cycloaddition (CuAAC) click reaction has been developed to combine advantages of photochemistry including spatial and temporal controls with the CuAAC reaction [31-34]. Furthermore, some drawbacks of the CuAAC process such as sensitivity of toxic copper (I) against the air, which leads to the deactivation of the catalyst and reduce the yield, and lack of possibility to effect the reaction with external stimuli have been eliminated $[30,35]$. The in-situ generation of $\mathrm{Cu}(\mathrm{I})$ catalyst has been also achieved by using either suitable reduction agent, or other chemical or electrochemical ways [36-38]. The photoinduced-CuAAC process has been utilized for synthesis of various complex macromolecular structures involving 
telechelic and star polymers, block and graft copolymers, gels and bioconjugation [33,35,39-50]. In this study, an antibacterial thermoset containing AgNPs is successfully prepared by combination of simultaneous photoinduced electron transfer and photoinduced CuAAC processes in one-pot. The photochemically generated radicals not only used to generate $\mathrm{Ag}^{0}$ nanoparticles from $\mathrm{Ag}^{+}$cation, but also reduce the $\mathrm{Cu}(\mathrm{II})$ into $\mathrm{Cu}(\mathrm{I})$ catalyst, which enable to catalyze the CuAAC of multifunctional azide and alkyne compounds. Thus, the desired antibacterial thermoset material can be simply fabricated at room temperature.

\section{Material and methods}

\subsection{Materials}

2, 2-dimethoxy-2-phenyl acetophenone (DMPA, 99\%, Aldrich), copper (II) bromide $\left(\mathrm{CuBr}_{2}, \geq 98.0 \%\right.$, Aldrich), silver nitrate (AgNO3, ACS grade, Merck), 1,1,1-tris[4-(2-propynyloxy)phenyl]-ethane ( $\geq 98 \%$, TCI Chemicals), propargyl bromide (80 wt.\% in toluene, Aldrich), trimethylolpropane triglycidyl ether (TTE, technical grade, Aldrich), sodium azide $\left(\mathrm{NaN}_{3}, 99 \%\right.$, Merck), sodium hydroxide $\left(\mathrm{NaOH}\right.$, ACS grade, Merck) and potassium carbonate $\left(\mathrm{K}_{2} \mathrm{CO}_{3}\right.$, $\geq 99 \%$, Sigma-Aldrich,) were used as received. $N, N, N^{\prime}, N^{\prime \prime}, N^{\prime \prime \prime}-$ Pentamethyl diethylenetriamine (PMDETA, $\geq 98 \%$, Merck) was distilled over sodium hydroxide before use. Commercial grade solvents (methanol, chloroform, dimethylsulfoxide and $\mathrm{N}, \mathrm{N}$ dimethylformamide) were purchased from Merck and used as received.

1,1,1-Tris[4-(2-propynyloxy) phenyl]-ethane (Tris-alkyne) [51,52] and 3,3'-((2-((3-azido-2-hydroxypropoxy)methyl)-2ethylpropane-1,3-diyl)bis(oxy))bis(1-azidopropan-2-ol) (TTE- $\mathrm{N}_{3}$ ) $[1,53]$ were prepared according to the literature procedures.

\subsection{Methods}

The Perkin-Elmer FT-IR Spectrum One B spectrometer was used for FT-IR analysis. The Agilent NMR System VNMRS 500 spectrometer was used at room temperature in $\mathrm{CDCl}_{3}$ with $\mathrm{Si}\left(\mathrm{CH}_{3}\right)_{4}$ as an internal standard for ${ }^{1} \mathrm{H}$ NMR analyses. The thermogravimetric analysis was conducted by Perkin-Elmer Diamond TA/TGA with a heating rate of $10^{\circ} \mathrm{C} / \mathrm{min}$ under nitrogen flow $(200 \mathrm{~mL} / \mathrm{min})$. Transmission electron microscopy (TEM) observation was performed on a FEI Tecnai ${ }^{\mathrm{TM}} \mathrm{G}^{2} \mathrm{~F} 30$ electron microscope operating at $200 \mathrm{kV}$. The ultrathin TEM specimens around $100 \mathrm{~nm}$ were cut by a cryoultramicrotome $\left(\mathrm{EMUC}_{6}+\mathrm{EMFC}_{6}\right.$, Leica) equipped with a diamond knife. Before TEM analyses, the obtained specimens were located on holey carbon-coated grid. The solubility properties were determined using ASTM D3132-84 (1996): standard test method for solubility range of resins and polymers. The color and dissolution of the samples were observed after immersing them in solvent $(5 \% \mathrm{w} / \mathrm{v}$ in solvent, acetone, chloroform, $N, N$-dimethylacetamide, dimethyl sulfoxide, methanol, and tetrahydrofuran) at room temperature for 4 days.

\subsection{In-situ preparation of antibacterial thermosets}

All formulations contain same amounts of TTE- $\mathrm{N}_{3}$ (506 mg, $1.17 \mathrm{mmol}$ ): Tris-alkyne (494 mg, $1.17 \mathrm{mmol}): \mathrm{Cu}(\mathrm{II}) \mathrm{Br}_{2}(5.2 \mathrm{mg}$, $0.023 \mathrm{mmol}):$ PMDETA $(30 \mu \mathrm{L}, 0.14 \mathrm{mmol}):$ DMPA (36 mg, $0.14 \mathrm{mmol})=50: 50: 1: 6: 6$, except $\mathrm{AgNO}_{3}$ with different loadings (1, 3, 5 and $10 \%$ of the monomers by weight). They were dissolved with DMF $(0.2 \mathrm{~mL})$ in a Pyrex tube and de-aerated by bubbling nitrogen gas for $10 \mathrm{~min}$ and the tube was irradiated for $30 \mathrm{~min}$ by a merry-go-round type photoreactor equipped with 12 Philips $8 \mathrm{~W} / 06$ lamps emitting light at $\lambda>350 \mathrm{~nm}$ and a cooling system [54]. At the end of given time, the products washed with excess methanol and filtered. The product was then dried in a vacuum oven at room temperature overnight. Solubility of thermosets was tested by adding $20 \mathrm{mg}$ of each sample to $10 \mathrm{~mL}$ solvent for $24 \mathrm{~h}$ at room temperature.

\subsection{Antibacterial test}

The effect of Ag NPs on Gram negative(pathogenic and non-pathogenic) and Gram-positive, pathogenic bacteria was investigated according to the agar diffusion method [8]. Initially, strains were cultured on the medium at $37 \mathrm{C}$ for $18 \mathrm{~h}$. After that, the cultured organisms were added to $10 \mathrm{~mL}$ of saline solution $(0.9 \%$ $\mathrm{NaCl}$ ) to reach approximately the $10^{5}$ colony forming units per milliliter (CFU mL $\left.{ }^{-1}\right)$. Each thermoset sample $(30 \mathrm{mg})$ was placed in the middle of sterilized Petri dishes. Then, $1 \mathrm{~mL}$ of saline solution containing bacteria and agar solution were added onto the surface of each material. After incubation for $24 \mathrm{~h}$ at $37^{\circ} \mathrm{C}$, a clear and distinct zone of inhibition was visualized surrounding the samples implying the antimicrobial activity against the microorganisms.

\section{Results and discussion}

By using multifunctional azide and alkyne compounds, thermoset networks were simply formed via CuAAC click reaction under mild condition [55]. For instance, photoinduced CuAAC chemistry was utilized for the building thermoset network with a high cross-linked density [31,32,56-58]. Because of their structural characteristics that have stiffer triazole linkages, these polymers exhibited higher glass transition temperatures and mechanical properties than thiol-ene networks of similar crosslinking density

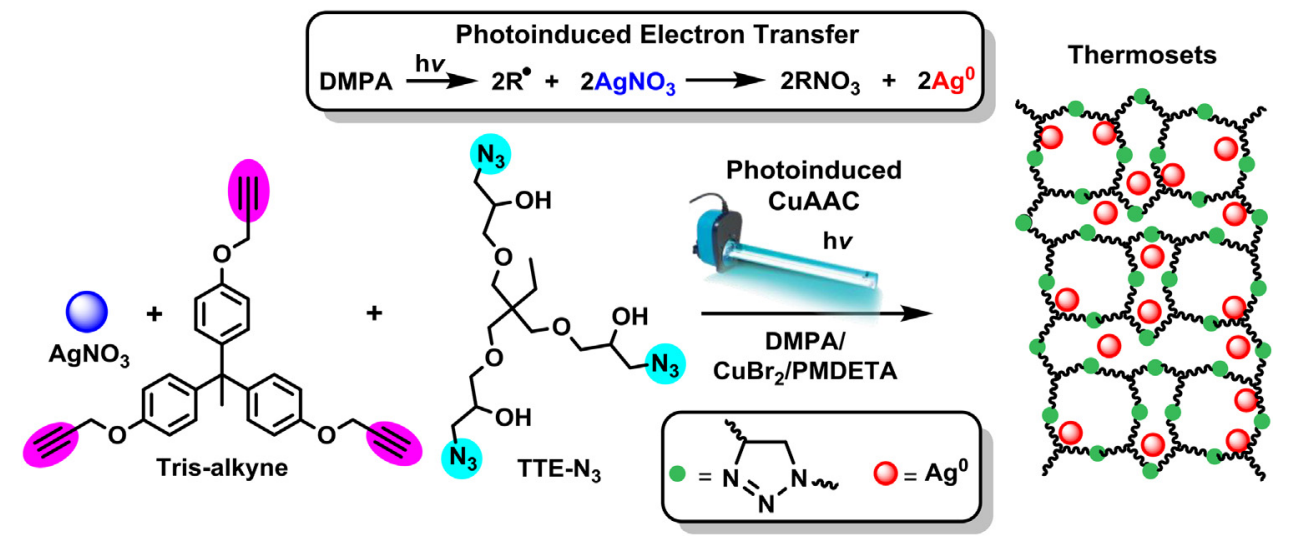

Scheme 1. Preparation of thermoset polymers containing silver nanoparticles via simultaneous photoinduced electron transfer and CuAAC processes. 


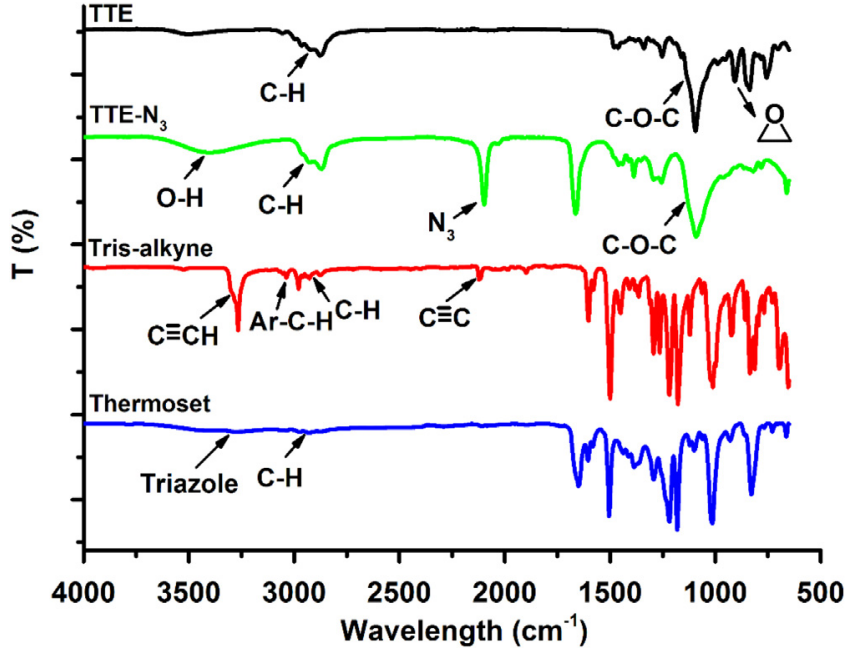

Fig. 1. Monitoring the formation of thermoset containing silver nanoparticles by FT-IR spectroscopy.
[59]. In our case, Tris-alkyne and TTE- $\mathrm{N}_{3}$ compounds were synthesized and characterized according to the literature procedures. Their structures, confirmed by FT-IR and ${ }^{1} \mathrm{H}$ NMR techniques, were in accordance with respect to the literature data. The characteristic bands belonging to propargyl group of Tris-alkyne were detected at 2120 and $3260 \mathrm{~cm}^{-1}$ in FT-IR spectrum, whereas the alkyne and methylene protons were visualized with proper integrations at 2.5 and $4.7 \mathrm{ppm}$ in ${ }^{1} \mathrm{H}$ NMR spectrum. Similarly, the disappearance of characteristic epoxy band at $905 \mathrm{~cm}^{-1}$ and appearance of characteristic azide and hydroxyl bands at 2090 and $3500 \mathrm{~cm}^{-1}$ were clear evidence of the TTE- $\mathrm{N}_{3}$. In addition, a proton next to the azide group was seen at $3.8 \mathrm{ppm}$ in ${ }^{1} \mathrm{H}$ NMR spectrum. After successful synthesis of multifunctional clickable Tris-alkyne and TTE- $\mathrm{N}_{3}$, thermoset networks were obtained from fixed formulations (Tris-alkyne: TTE$\mathrm{N}_{3}: \mathrm{Cu}(\mathrm{II}) \mathrm{Br}_{2}$ : PMDETA: DMPA= 50:50:1:6:6) containing various amount of silver nitrate under UV irradiation (Scheme 1). The crosslinking reaction were formed by $\mathrm{CuAAC}$ click reaction between azide and alkyne groups, which was catalyzed by photochemically generated $\mathrm{Cu}(\mathrm{I})$ ions. The reduction of $\mathrm{Cu}(\mathrm{II}) \mathrm{Br}_{2}$ salt into $\mathrm{Cu}(\mathrm{I})$ activator was efficiently accomplished by radicals of generated from photolysis of DMPA. On the other hand, these photogenerated rad-
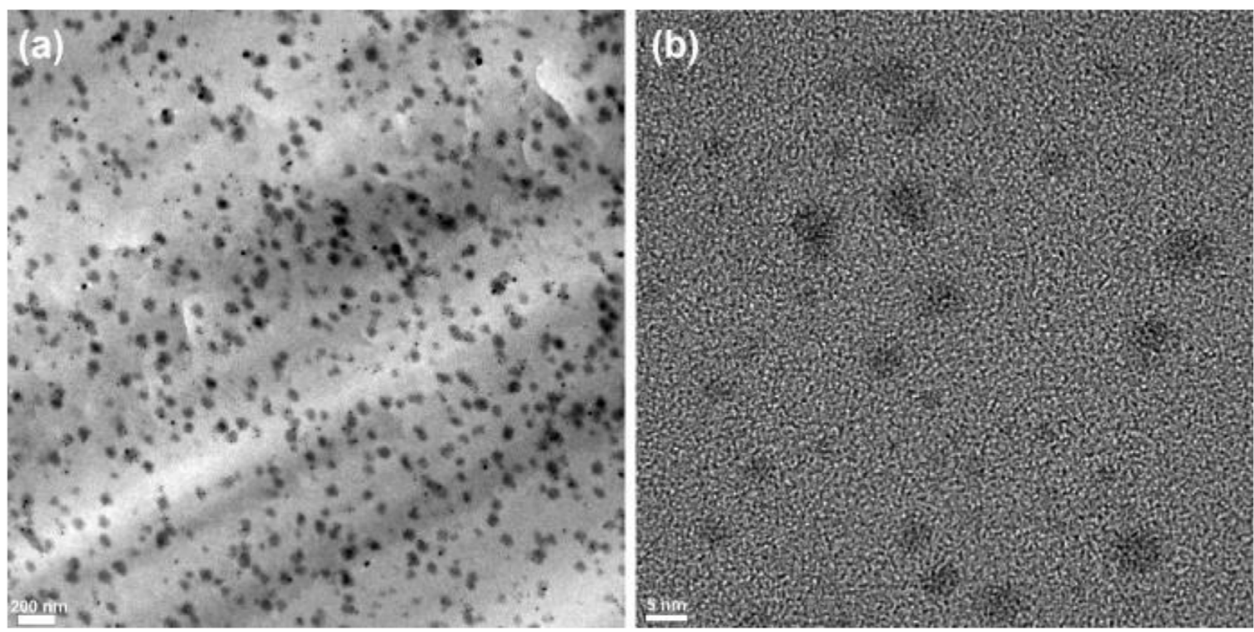

Fig. 2. TEM micrographs of thermoset containing AgNPs ( 3 wt $\mathrm{AgNO}_{3}$ ) in (a) low (scale bar: $200 \mathrm{~nm}$ ) and (b) high (scale bar: $5 \mathrm{~nm}$ ) magnifications.
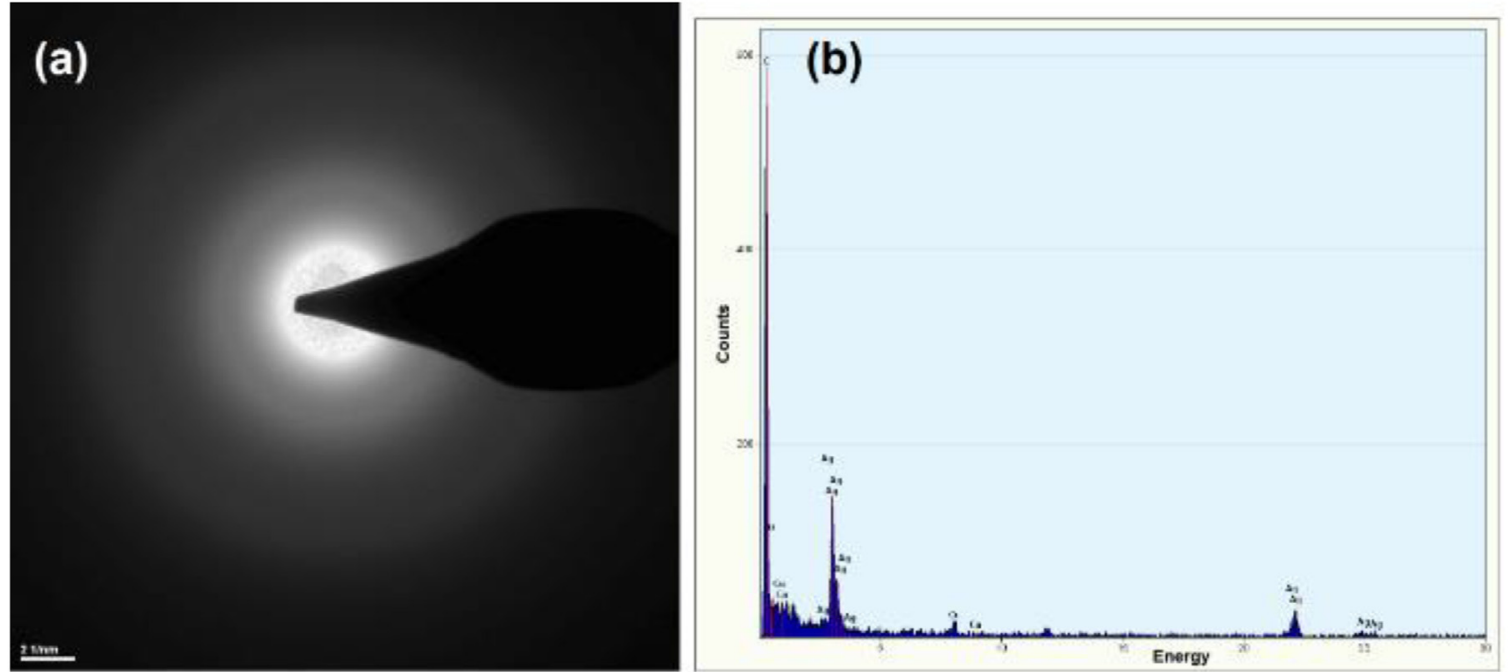

Fig. 3. Selected area electron diffraction pattern (a) and energy dispersive X-ray (EDX) spectrum (b) of the thermoset sample containing $\mathrm{AgNPs}\left(3 \mathrm{wt} \% \mathrm{AgNO}_{3}\right.$ ). 


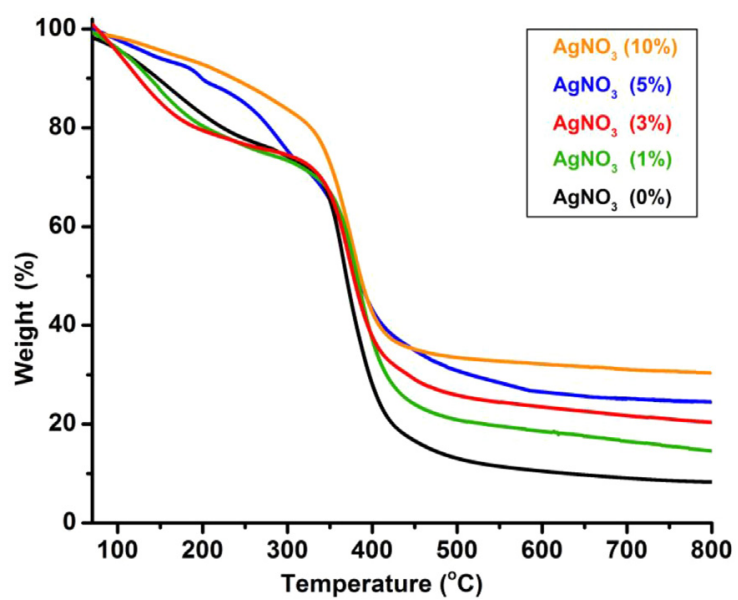

Fig. 4. TGA thermograms of thermoset containing silver nanoparticles with various loadings $1,3,5$ and $10 \%$ of monomers by weight.

icals could be also utilized for the reduction of $\mathrm{Ag}(\mathrm{I})^{+}$cation into $\mathrm{Ag}(0)$ nanoparticles via photoinduced electron transfer reaction. Indeed, two different reduction processes were in competence with the radicals formed from the photolysis of the DMPA. Since the reduction potential of $\mathrm{Cu}(\mathrm{II})$ into $\mathrm{Cu}(\mathrm{I})\left(+0.153 \mathrm{E}^{\circ}(\mathrm{V})\right)$ was smaller than $\mathrm{Ag}(\mathrm{I})$ into $\mathrm{Ag}(0)\left(+0.799 \mathrm{E}^{\circ}(\mathrm{V})\right)$, therefore, the CuAAC click reaction was catalyzed before the formation of AgNPs [60]. In fact, this preference enabled to prepare the crosslinked template beforehand and not only eliminate the agglomeration of AgNPs, but also retain their nanoparticle size.
With this template advantage, antibacterial thermosets containing AgNPs with different loadings were prepared under UV irradiation. The crosslinking process was monitored by FT-IR spectroscopy and the characteristic peaks of azide $\left(2090 \mathrm{~cm}^{-1}\right)$ and alkyne $\left(\mathrm{C} \equiv \mathrm{C}-\mathrm{H}\right.$ and $\mathrm{C} \equiv \mathrm{C}, 3260$ and $2120 \mathrm{~cm}^{-1}$ ) were completely disappeared after the photoinduced $\mathrm{CuAAC}$ click reaction. In addition, a new weak band corresponding to $\mathrm{N}-\mathrm{H}$ bond of triazole ring was seen around $3310 \mathrm{~cm}^{-1}$ in Fig. 1 . Accroding to these results, almost quantitative yields were observed from the click reactions that proceed at ambient conditions. The formation of thermoset polymers was also confirmed by solubility test using several solvents acetone, chloroform, $N, N$-dimethylacetamide, dimethyl sulfoxide, methanol, and tetrahydrofuran. All samples were insoluble and color of the solutions were almost transparent, implying their highly crosslinked structures.

In order to confirm the size and distribution of the AgNPs, transmission electron microscopy (TEM) with energy dispersive X-ray system (EDX) analyzer was performed for thermoset sample containing AgNPs ( $3 \mathrm{wt} \% \mathrm{AgNO}_{3}$ ). The dark spheres represented the AgNPs, whereas the gray areas were corresponded to the thermoset matrix. It was clearly observable that the thermoset sample was built from densely packed AgNPs with non-uniform size distributions between 3 and $80 \mathrm{~nm}$. Furthermore, no agglomerated AgNPs were observed in both low and high magnifications (Fig. 2). The interaction between AgNPs and the polymer matrix enabled the diffusion-limited growth of AgNPs to prevent their possible agglomeration during the process.

The energy dispersive X-ray (EDX) spectrometer analysis confirmed the presence of elemental silver signal of the silver nanoparticles, where peaks around 3.522 .3 and $25.1 \mathrm{keV}$ were assigned to the binding energies of $\mathrm{Ag}_{\mathrm{L}}, \mathrm{Ag} \mathrm{Ka} \mathrm{Ka}_{1}$ and $\mathrm{Ag} \mathrm{Ka}$, respectively (Fig. 3b). Furthermore, the selected area EDX pattern of the

\section{Escherichia Coli Staphylococcus Aureus Control Experiment}

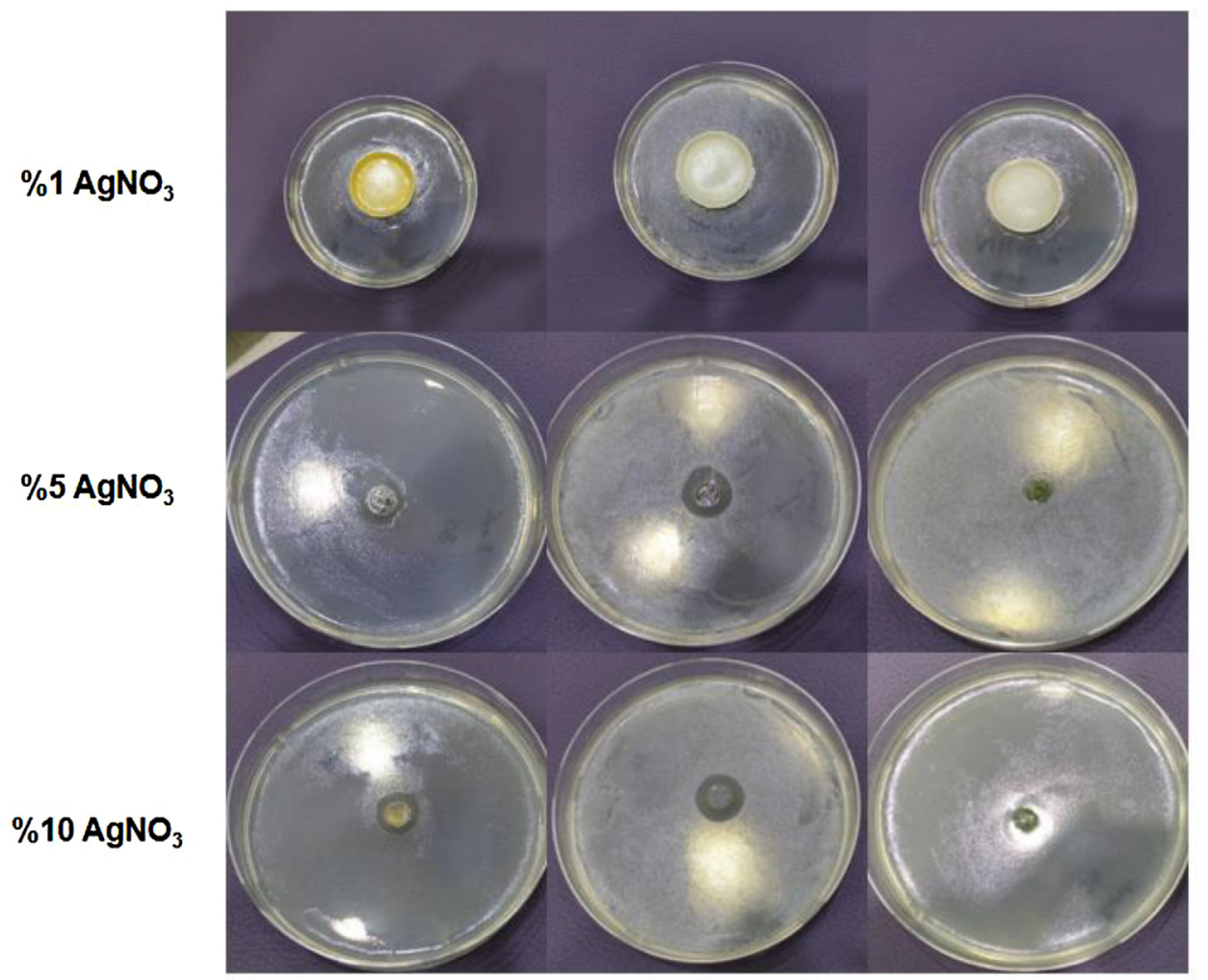

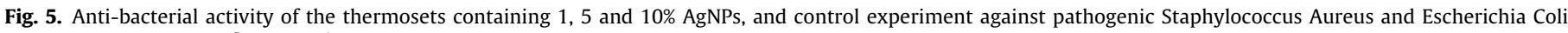
bacteria (Cell density: $10^{5} \mathrm{CFU} \mathrm{mL}^{-1}$ ). 
sample displayed concentric rings, indicating that these AgNPs had highly crystalline structures (Fig. 3a). In addition, other peaks corresponding to $\mathrm{CuK}_{\mathrm{a}}$ and $\mathrm{CuK}_{\mathrm{b}}$ in the EDX were detected at binding energies of 1.6, 8.1 and $8.9 \mathrm{keV}$. The $\mathrm{Cu}$ peaks could be related to the copper of the CUAAC catalyst or TEM holding grid, in which the sample was coated. Also, sharp peaks near $1.0 \mathrm{keV}$ corresponding of carbon and oxygen atoms of thermosets were clearly observed. Overall, these results undoubtedly confirmed the presence of both components (AgNPs and polymeric matrix) of the antibacterial thermosets.

Thermal behavior of the samples was investigated by thermogravimetric analysis with a heating rate of $10^{\circ} \mathrm{C} / \mathrm{min}$ under nitrogen atmosphere. All samples exhibited two-step degradation process in the range of $150-320^{\circ} \mathrm{C}$ and $320-500^{\circ} \mathrm{C}$. The first decomposition was attributed to the bond cleavage of $\mathrm{C}-\mathrm{O}-\mathrm{C}$ and dehydration of free hydroxyl groups in the network. The second degradation corresponded to the depolymerization reaction involving the scission of $\mathrm{C}-\mathrm{C}$ bonds, resulting to the complete degradation of the carbonaceous materials and char forming (Fig. 4). It was also noted that the char yield increased with the addition of the $\mathrm{AgNO}_{3}$. For example, the char content of sample containing $10 \% \mathrm{AgNO}_{3}$ increased approximately three fold (30\%) compared with neat thermoset (13\%). The increase in char yield was directly related to determine the AgNPs formation. Thus, the yield of AgNPs formation in thermoset was increased in order of $\mathrm{AgNO}_{3}$ loadings.

The antibacterial activities of thermoset samples containing AgNPs formed by photoinduced electron transfer during curing process were investigated against gram-positive (Staphylococcus Aureus) and gram-negative (Escherichia Coli) bacteria as shown in Fig. 5. The antibacterial activity was attributed to its neutral form, in which the passage through the cell wall followed by strong interactions with cellular components [8]. Nutrient agar plates were inoculated with $10^{5} \mathrm{CFU} \mathrm{mL}-1$ from different bacterial strains. The samples containing 5 and 10\% AgNPs exhibited strong inhibition zones, where all kinds of bacteria were killed in the surrounding of the film samples. The inhibition zone from gram positive bacteria was slightly larger than the zone from gram negative bacteria, but all zones were clear around the close proximity of film samples containing AgNPs. Whereas, the control sample without AgNPs and sample containing $1 \%$ AgNPs did not displayed any zone after incubation for $24 \mathrm{~h}$ at $37^{\circ} \mathrm{C}$, indicating that there was no antibacterial activity against to the bacterial growth.

\section{Conclusions}

In conclusion, in-situ preparation of thermosets containing AgNPs was achieved by simultaneous photoinduced electron transfer and CuAAC processes using multifunctional azide and alkyne molecules in the presence of DMPA and $\mathrm{AgNO}_{3}$. The photogenerated radicals not only reduce $\mathrm{Cu}(\mathrm{II})$ into $\mathrm{Cu}(\mathrm{I})$ activator to catalyst the CuAAC click reaction, but also produce AgNPs from $\mathrm{AgNO}_{3}$ through photoinduced electron transfer. To take advantage of reduction potentials difference, the CuAAC click reaction was catalyzed before the formation of AgNPs, enabling to eliminate the agglomeration of AgNPs in the polymer matrix. The highly crosslinked structures of the samples were principally confirmed by FT-IR and solubility tests, which were not soluble in various organic solvents. The TEM with EDX results undoubtedly confirmed the presence of AgNPs with non-uniform size distributions in the polymer matrix. It was also shown that all products exhibited antibacterial activities against to gram positive (Staphylococcus Aureus) and gram negative (Escherichia Coli) bacterial colonies. By applying this strategy, limitations such as high cost and complicated experimental procedures for the preparation of antibacterial material are eliminated and its production has become easier than previous one.

\section{Acknowledgement}

The authors would like to thank Yalova University Research Fund (Project no: 2015/YL/054) for financial supports.

\section{References}

[1] D. Davies, Nat. Rev. Drug Discov. 2 (2003) 114-122.

[2] T. Tashiro, Macromol. Mater. Eng. 286 (2001) 63-87.

[3] F. Paladini, M. Pollini, A. Sannino, L. Ambrosio, Biomacromolecules 16 (2015) 1873-1885.

[4] J.A. Lichter, K.J. Van Vliet, M.F. Rubner, Macromolecules 42 (2009) 8573-8586

[5] I. Sondi, B. Salopek-Sondi, J. Colloid Interface Sci. 275 (2004) 177-182.

[6] V.K. Sharma, R.A. Yngard, Y. Lin, Adv. Colloid Interface Sci. 145 (2009) 83-96.

[7] C.N. Lok, C.M. Ho, R. Chen, Q.Y. He, W.Y. Yu, H. Sun, P.K.H. Tam, J.F. Chiu, C.M. Che, J. Biol. Inorg. Chem. 12 (2007) 527-534.

[8] M. Uygun, M.U. Kahveci, D. Odaci, S. Timur, Y. Yagci, Macromol. Chem. Phys. 210 (2009) 1867-1875.

[9] M. Sangermano, Y. Yagci, G. Rizza, Macromolecules 40 (2007) 8827-8829.

[10] Y. Yagci, M. Sangermano, G. Rizza, Polymer 49 (2008) 5195-5198.

[11] O. Eksik, M.A. Tasdelen, A.T. Erciyes, Y. Yagci, Compos. Interfaces 17 (2010) 357-369.

[12] Y. Yagci, O. Sahin, T. Ozturk, S. Marchi, S. Grassini, M. Sangermano, React. Funct. Polym. 71 (2011) 857-862.

[13] M. Sangermano, F. Vivier, G. Rizza, Y. Yagci, J. Macromol. Sci. Part A Pure Appl. Chem. 51 (2014) 511-513.

[14] C. Lorenzini, A. Haider, I.-K. Kang, M. Sangermano, S. Abbad-Andalloussi, P.-E. Mazeran, J. Lalevée, E. Renard, V. Langlois, D.-L. Versace, Biomacromolecules 16 (2015) 683-694.

[15] M. Mehrabanian, D. Fragouli, D. Morselli, A. Scarpellini, G.C. Anyfantis, A. Athanassiou, Mater. Res. Express 2 (2015) 105014.

[16] K. Ito, A. Saito, T. Fujie, H. Miyazaki, M. Kinoshita, D. Saitoh, S. Ohtsubo, S. Takeoka, J. Biomed. Mater. Res. B Appl. Biomater. 104 (2016) 585-593.

[17] S. Borse, M. Temgire, A. Khan, S. Joshi, RSC Adv. 6 (2016) 56674-56683.

[18] M. Marini, S. De Niederhausern, R. Iseppi, M. Bondi, C. Sabia, M. Toselli, F. Pilati, Biomacromolecules 8 (2007) 1246-1254.

[19] S. Tarimala, N. Kothari, N. Abidi, E. Hequet, J. Fralick, L.L. Dai, J. Appl. Polym. Sci. 101 (2006) 2938-2943.

[20] G. Yang, J.J. Xie, Y.X. Deng, Y.G. Bian, F. Hong, Carbohydr. Polym. 87 (2012) 2482-2487

[21] J.J. Wu, N. Zhao, X.L. Zhang, J. Xu, Cellulose 19 (2012) 1239-1249.

[22] K. Ghanbari, Synth. Met. 195 (2014) 234-240.

[23] A. Alqudami, S. Annapoorni, P. Sen, R.S. Rawat, Synth. Met. 157 (2007) 53-59.

[24] I. Donati, A. Travan, C. Pelillo, T. Scarpa, A. Coslovi, A. Bonifacio, V. Sergo, S. Paoletti, Biomacromolecules 10 (2009) 210-213.

[25] A. Gautam, G.P. Singh, S. Ram, Synth. Met. 157 (2007) 5-10.

[26] M.A. Tasdelen, Y. Yagci, Aust. J. Chem. 64 (2011) 982-991.

[27] K.D. Demir, M. Kukut, M.A. Tasdelen, Y. Yagci, Therm. Nanocompos. (2013) $165-188$.

[28] M.A. Tasdelen, V. Kumbaraci, S. Jockusch, N.J. Turro, N. Talinli, Y. Yagci, Macromolecules 41 (2008) 295-297.

[29] M.U. Kahveci, M.A. Tasdelen, Y. Yagci, Polymer 48 (2007) 2199-2202.

[30] M.A. Tasdelen, Y. Yagci, Angew. Chem. Int. Ed. 52 (2013) 5930-5938.

[31] B.J. Adzima, Y. Tao, C.J. Kloxin, C.A. DeForest, K.S. Anseth, C.N. Bowman, Nat. Chem. 3 (2011) 256-259.

[32] T. Gong, B.J. Adzima, N.H. Baker, C.N. Bowman, Adv. Mater. 25 (2013) 2024-2028.

[33] Y. Yagci, M.A. Tasdelen, S. Jockusch, Polymer 55 (2014) 3468-3474.

[34] M.A. Tasdelen, Y. Yagci, Tetrahedron Lett. 51 (2010) 6945-6947.

[35] M.A. Tasdelen, B. Kiskan, Y. Yagci, Prog. Polym. Sci. 52 (2016) 19-78.

[36] S.K. Mamidyala, M.G. Finn, Chem. Soc. Rev. 39 (2010) 1252-1261.

[37] R. Manetsch, A. Krasiński, Z. Radić, J. Raushel, P. Taylor, K.B. Sharpless, H.C. Kolb, J. Am. Chem. Soc. 126 (2004) 12809-12818.

[38] W.G. Lewis, L.G. Green, F. Grynszpan, Z. Radić, P.R. Carlier, P. Taylor, M.G. Finn, K.B. Sharpless, Angew. Chem. Int. Ed. 41 (2002) 1053-1057.

[39] M.A. Tasdelen, G. Yilmaz, B. Iskin, Y. Yagci, Macromolecules 45 (2012) 56-61.

[40] G. Yilmaz, B. Iskin, Y. Yagci, Macromol. Chem. Phys. 215 (2014) 662-668.

[41] O. Yetiskin, S. Dadashi-Silab, S.B. Khan, A.M. Asiri, Y. Yagci, Asian J. Org. Chem. 4 (2015) 442-444.

[42] E. Murtezi, Y. Yagci, Macromol. Rapid Commun. 35 (2014) 1782-1787.

[43] S. Doran, G. Yilmaz, Y. Yagci, Macromolecules 48 (2015) 7446-7452.

[44] S. Doran, Y. Yagci, Polym. Chem. 6 (2015) 946-952.

[45] S. Dadashi-Silab, B. Kiskan, M. Antonietti, Y. Yagci, RSC Adv. 4 (2014) 52170-52173.

[46] H.B. Tinmaz, I. Arslan, M.A. Tasdelen, J. Polym. Sci. Part A: Polym. Chem. 53 (2015) 1687-1695.

[47] M.A. Tasdelen, O.S. Taskin, C. Celik, Macromol. Rapid Commun. 37 (2016) 521-526.

[48] G. Demirci, M.A. Tasdelen, Eur. Polym. J. 66 (2015) 282-289.

[49] I. Arslan, M.A. Tasdelen, Des. Monomers Polym. 19 (2016) 155-160. 
[50] S. Chatani, C.J. Kloxin, C.N. Bowman, Polym. Chem. 5 (2014) 2187-2201.

[51] K.P. Unnikrishnan, E.T. Thachil, Des. Monomers Polym. 9 (2006) 129-152.

52] D. Ratna, Handbook of Themoset Resins, Ismithers, Shropshire, 2009.

[53] P. Penczek, Z. Klosowska Wolkowicz, Polimery 42 (1997) 294-298.

[54] M.A. Tasdelen, A.L. Demirel, Y. Yagci, Eur. Polym. J. 43 (2007) 4423-4430.

[55] D.D. Díaz, S. Punna, P. Holzer, A.K. McPherson, K.B. Sharpless, V.V. Fokin, M.G. Finn, J. Polym. Sci. Part A: Polym. Chem. 42 (2004) 4392-4403.

[56] H.B. Song, A. Baranek, C.N. Bowman, Polym. Chem. 7 (2016) 603-612.

[57] D. Konetski, T. Gong, C.N. Bowman, Langmuir 32 (2016) 8195-8201.
[58] M.K. McBride, T. Gong, D.P. Nair, C.N. Bowman, Polymer 55 (2014) 5880-5884.

[59] A. Baranek, H.B. Song, M. McBride, P. Finnegan, C.N. Bowman, Macromolecules 49 (2016) 1191-1200.

[60] W. Brey, Physical Chemistry and Its Biological Applications, Elsevier Science, Burlington, 2012, page 219. 